\title{
Carotid body tumour associated with cyanotic heart disease
}

\author{
Jason K C Mak, ${ }^{1}$ Mark Kay ${ }^{2}$
}

${ }^{1}$ University of Birmingham, Birmingham, UK

${ }^{2}$ Department of Vascular Surgery, University Hospitals Birmingham NHS Foundation Trust, Birmingham, UK

\section{Correspondence to} Jason K C Mak jason.mak@hotmail.co.uk

Accepted 23 February 2016

\section{DESCRIPTION}

We report a case of a 60-year-old woman with a history of cyanotic heart disease who presented with a painless and palpable left-sided anterior neck mass. Clinical examination did not reveal any cranial nerve palsy. Soft systolic and diastolic murmurs were heard on auscultation and the patient also suffered from persistent shortness of breath $\left(\mathrm{O}_{2}\right.$ saturation approximately 90\%). Previously, transoesophageal echocardiography had demonstrated a large fenestrated secundum atrial septal defect with right-to-left shunting. There was no relevant family history.

A contrast-enhanced neck CT scan revealed a highly vascular and well-circumscribed $2.2 \times 2.0 \mathrm{~cm}$ paraganglioma at the left carotid bifurcation (figure 1), intimately encasing the external carotid artery (ECA). Several enlarged feeding branches arising from the ECA could be observed. The carotid body tumour (CBT) resulted in characteristic splaying of the internal and external carotid arteries (figure 2), but peak-systolic and end-diastolic velocities were within normal ranges.

The carotid body consists of chemoreceptors that are exquisitely sensitive to reduced arterial $\mathrm{pO}_{2}$ levels. CBTs have traditionally been categorised into sporadic, familial and hyperplastic forms. Of specific relevance in this case, the hyperplastic type arose from chronic hypoxaemia, which can be induced by cyanotic heart disease. ${ }^{1-3}$ Complete surgical excision of the CBT was subsequently undertaken with the ECA and vagus nerve preserved. The patient made a full recovery without major postoperative complications.

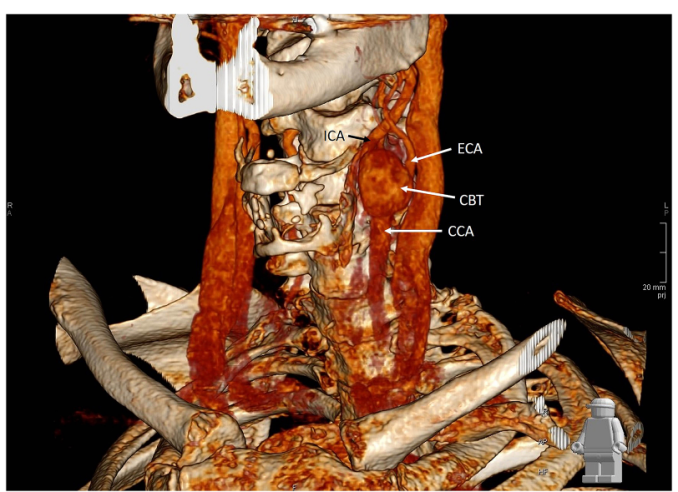

Figure 1 Contrast-enhanced CT image of the neck (with volume rendered three-dimensional reconstruction) showing a hypervascularised paraganglioma located at the left carotid bifurcation. CBT, carotid body tumour; CCA, common carotid artery; ECA, external carotid artery; ICA, internal carotid artery.

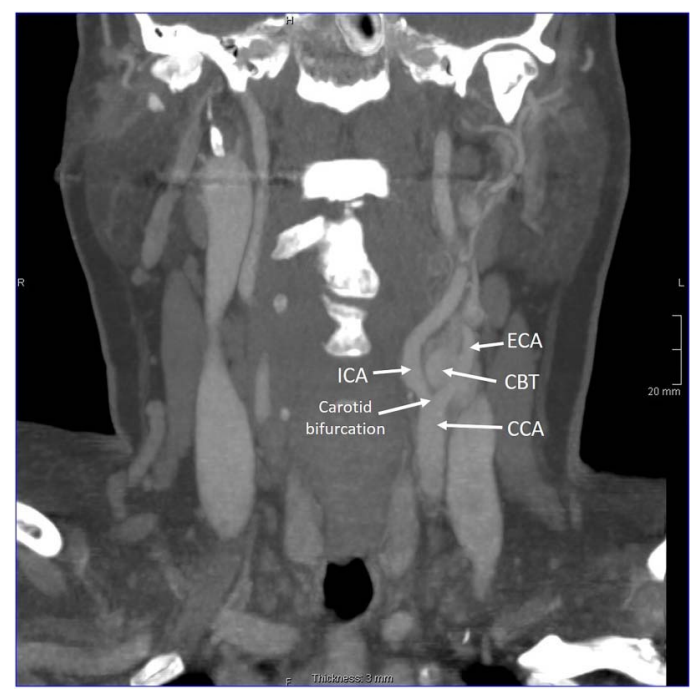

Figure 2 Contrast-enhanced CT image of the neck demonstrating characteristic splaying of the left internal and external carotid arteries ('lyre sign') caused by the carotid body tumour. CBT, carotid body tumour; CCA, common carotid artery; ECA, external carotid artery; ICA, internal carotid artery.

Despite their low incidence, the present case highlights the importance of excluding CBTs as a potential cause of an anterior neck mass in patients with a history of cyanotic heart disease.

\section{Learning points}

- Carotid body tumours (CBTs) are rare and classically present as benign, unilateral anterior neck masses; complete surgical resection is currently the treatment of choice.

- Certain congenital heart defects contribute to the pathogenesis of hyperplastic CBTs via the induction of chronic hypoxaemia, although the exact mechanism(s) remain unclear.

- It is important to clinically assess the presence of cyanotic heart disease in patients presenting with a CBT; echocardiography is recommended as a valuable additional diagnostic tool.

Contributors JKCM identified the case as being of particular interest, conducted the research and wrote the manuscript. MK provided the clinical images and was involved in revision of the drafts. Both authors approved the final version for publication.

Competing interests None declared.

Patient consent Obtained. 


\section{Images in...}

Provenance and peer review Not commissioned; externally peer reviewed.

\section{REFERENCES}

1 Nissenblatt MJ. Cyanotic heart disease: "Low altitude" risk for carotid body tumor? Johns Hopkins Med J 1978;142:18-22.
2 de la Monte SM, Hutchins GM, Moore GW. Peripheral neuroblastic tumors and congenital heart disease. Possible role of hypoxic states in tumor induction. Am J Pediatr Hematol Oncol 1985;7:109-16.

3 Yildiz BS, Sasmazel A, Baysal A, et al. Assessment of carotid body tumor and its association with Tetralogy of Fallot: effect of the chronic hypoxia. Heart Views 2014;15:86-8.

Copyright 2016 BMJ Publishing Group. All rights reserved. For permission to reuse any of this content visit http://group.bmj.com/group/rights-licensing/permissions.

BMJ Case Report Fellows may re-use this article for personal use and teaching without any further permission.

Become a Fellow of BMJ Case Reports today and you can:

- Submit as many cases as you like

- Enjoy fast sympathetic peer review and rapid publication of accepted articles

- Access all the published articles

- Re-use any of the published material for personal use and teaching without further permission

For information on Institutional Fellowships contact consortiasales@bmjgroup.com

Visit casereports.bmj.com for more articles like this and to become a Fellow 